\author{
Franz-Karl Ehrhard
}

\title{
The Register of the Reliquary of Lord Rañ-Rig Ras-Pa
}

\author{
For Albrecht Wezler \\ friend of India, Nepal and Tibet \\ on the occasion of his sixty-fifth birthday
}

A work quite popular among Tibetan travellers and pilgrims in Nepal was a particular "register" (dkar chag) describing the Svayambhūnāth Stūpa and the further sacred sites in the Kathmandu Valley. It has been used as an important document for the study of the history of "Noble All [Kinds of] Trees" ('phags pa śin kun), ${ }^{1}$ as Tibetans call this most sacred edifice in the valley, because it contains descriptions of two renovations, respectively occurring at the beginning of the $16^{\text {th }}$ century and at the end of the $17^{\text {th }}$ century. The hypothesis has been proposed that "A Register of the Stūpa 'Noble All [Kinds of] Trees' in Nepal and Other Sacred Sites There" (bal yul mchod rten 'phags pa śin kun dain de'i gnas gźan rnams kyi dkar chag) was fixed in writing on the occasion of the renovation in the year 1680 . This renovation was undertaken at the initiative of Rań-rig ras-pa or Rań-rig ras-chen (d. 1683), a yogin of the 'Brug-pa school of Tibetan Buddhism who also held teaching transmissions of the rÑin-ma-pa school. In fact, the furnishing of the Svayambhūnāth Stūpa with a new central mast and further embellishments - which coincided with the beginning of the rulership of King Parthivendra Malla (regnal years 1680-1687) - was preceded by a renovation of the Bodhnāth Stūpa; this magnificent religious building in

1 The name "Noble All [Kinds of] Trees" reminds Tibetan pilgrims of the former presence of Nāgārjuna at the stūpa. According to the etiological story as contained in the pilgrimage guidebook under investigation, Nāgārjuna had cut off his hair and while scattering it around made the wish that all kinds of trees should grow at this noble stūpa; see Wylie, op.cit. (n. 4), p. 19, n. 35. For a critical attitude towards this etymology according to a Tibetan register of the sacred sites in the Kathmandu Valley from the $18^{\text {th }}$ century, see A.W. Macdonald - Dvags-po Rin-poche, Un guide peu-lu des lieux-saints du Nepal (IIe partie). In: Tantric and Taoist Studies in Honour of R.A. Stein. Vol 1. [Melanges Chinois et Bouddhiques 20]. Bruxelles: Institute Belge des Hautes Études Chinoises 1981, p. 245-246. 
the Kathmandu Valley is of special importance for the followers of Padmasambhava and his teaching traditions. The latter renovation is mentioned in the collection of "Spiritual Songs" (mgur) of Ran-rig raspa; by contrast no notice is taken of the renewal of the central part of the Svayaṃhūnāth Stūpa and other additions to the structure. ${ }^{2}$

The author of the register gives his name as Nag-dban rdo-rje from Nas-lun, "who had been nourished by the instructions of the Lord Ranrig ras-pa" (rje ran rig ras pa'i man nag gis 'tsho ba). Besides the fact that Nag-dban rdo-rje had been a close disciple of Ran-rig ras-pa, we do not have much further biographical data on him. At least we know that after the death of his teacher he stayed at lHa-gdon to the east of the mountain rTsib-ri in gTsan province - a famous sacred site of 'Brug-pa yogins - where he performed "memorial laudations" (sku bstod) on behalf of his guru for a great assemblage of religious practitioners; at that time Nag-dban rdo-rje was still remembered as having acted as the "steward" (gñer $p a$ ) of Ran-rig ras-pa. These pieces of information we owe to another collection of spiritual songs and instructions, in this case the one of bsTan-'dzin ras-pa (1644/46-1723), another yogin of the 'Brug-pa school. Born in the Muktinatth valley in Southern Mustang and founder of the famous Śel dGon-pa in the Dol-po region, bsTan-'dzin ras-pa was a member of the spiritual lineage of Ran-rig ras-pa by way of his teacher Ran-grol rdo-rje. ${ }^{3}$

2 See F.-K. Ehrhard, Further Renovations of Svayaṃbhūnāth Stūpa (from the $13^{\text {th }}$ to the $17^{\text {th }}$ Centuries). Ancient Nepal: Journal of the Department of Archaeology 123-125 (April-September 1991) 11-13. For Ran-rig ras-pa's position in the lineage of the tradition of the "Northern Treasures" (byan gter), the teachings of which he received from rGyal-sras Phyag-rdor nor-bu (d. 1658), the younger brother of the Third Yol-mo-ba sPrul-sku bsTan-'dzin nor-bu (1598-1644), see rJe btsun khyab bdag chen po ran் rig ras chen gyi gsun mgur dan źal gdams 'dri med bdud rtsi'i rlabs 'phren. [Smanrtsis Shesrig Spendzod 111]. Leh: D.W. Tashigang 1982, p. 343.4-344.5. The compiler of this collection of spiritual songs and instructions was Nag-dbań rdo-rje from Nas-lun.

3 See $r N a l$ 'byor gyi dbañ phyug bstan 'dzin ras pa'i źal gdams mgur du gsuns pa rnams (xylograph), NGMPP reel-no. L 257/27, fols. 33a/2ff. \& 48a/7ff. Both bs'Tan-'dzin ras-pa and sTag-rtse skyu-skye Mi-pham phun-tshogs śes-rab (16541715) had been disciples of the Second lCogs-grva sPrul-sku sÑan-grags dpal bzan-pa (1617-1680), another important 'Brug-pa bKa'-brgyud-pa master of the $17^{\text {th }}$ century. This Mi-pham Phun-tshogs śes-rab was active in the region of Northern Mustang, and the list of his teachers includes Ran-rig ras-pa. He composed two devotional works in honour of him; see Grub dban rain rig ras pa'i sku bstod kyi 'grel bśad (xylograph), 11 fols., NGMPP reel-no. L 100/24, and Grub dban rain rig źabs kyi rnam thar la gsol ba 'debs pa (xylograph), 7 fols., NGMPP reel-no. L 100/22 
The modern xylograph of the register of Nag-dban rdo-rje which circulated among Tibetan travellers and pilgrims was executed by a monk from the sGo-man college of 'Bras-spuns monastery with the financial help of a person bearing the name Sog-sprul Gu-ru. This designation stands for the so-called "Mongolian Lama" (sog bla) Gurudeva [= Guru bDe-ba], a dGe-lugs-pa teacher who in the 1950s founded the monastery of dGa'-ldan Chos-'phel glin near Bodhnāth Stūpa; he is known best among scholars as a publisher of Tibetan books in New Delhi. ${ }^{4}$

In this edition the text is called a "register-cum-history" (lo rgyus dkar chag), and it was obviously produced for the needs of Tibetan refugees pouring into Nepal after the exodus of 1959. In addition to the main body of the work it contains, after the short authorial colophon of Nag-dban rdo-rje and the printing colophon of the monk from sGoman, a section which could be called a spiritual exhortation for pilgrims. This section was written for people who actually performed the journey to Svayaṃbhūnāth Stūpa and the other sacred sites in the Kathmandu Valley. In it these pilgrimage places are set in a typological relationship to other places conducive to spiritual practice which the translator $1 \mathrm{Ho}_{\text {- }}$ brag Mar-pa (1012-1097) had prophesied to his disciple, the great yogin Mi-la-ras-pa (1028-1111). This is achieved by a literal quotation from the famous Mi la ras pa'i rnam mgur of gTsań-smyon Heruka (14521507 ) concerning the location and time when Mi-la-ras-pa and his future disciples would frequent these sites; the list in this quotation includes

(including further works). All three mentioned block prints were carved in the Mustang region and can be assigned to a particular style of printing of 'Brug-pa materials. To this tradition belongs also the xylograph of the biography of the Second lCogs-grva sPrul-sku, completed by Mi-pham phun-tshogs śes-rab in the year 1688 in Tsā-ri Dag-pa śel-ri and later carved on wooden blocks in Mustang;

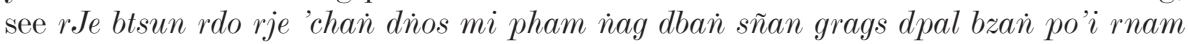
par thar pa no mtshar rgya mtsho'i zlos gar, 126 fols., in: The Biography of the Second sDin-po-che Cog-gra Mi-pham-Nag-dban-sñan-grags-dpal-bzain and Other Biographical Material Connected with the 'Brug-pa Dkar-brgyud-pa Tradition. Darjeeling: Chopal Lama 1984, p. 273-523.

4 It was this edition of the register which was edited in transliterated form by Turrell Wylie. For the printing colophon of the work see his A Tibetan Religious Geography of Nepal. [Serie Orientale Roma 42]. Rome: Istituto Italiano Per Il Medio Ed Estremo Oriente 1970, p. 48.9-25. Further information concerning the monastery of dGa'-ldan Chos-'phel glin, particularly its providing refuge for the monks and sacred items of sKyid-gron bSam-gtan glin, and its present role in the annual reconsecration of Bodhnāth Stūpa, is given by Y. Bentor, Consecration of Images and Stūpas in Indo-Tibetan Tantric Buddhism. [Brill's Indological Library 11]. Leiden - New York - Köln: E.J. Brill 1996, p. 71-75. 
La-stod rGyal-gyi śrī-ri, Gan̉s Ti-se, La-phyi gan̉s-ra, Mań-yul Ri-bo dpal-'bar, Bal-yul Yol-mo gañs-ra, Brin-gyi chu-dbar, gNas-chen Devikoți and Tsā-ri, but does not mention any site in the Kathmandu Valley.

Nevertheless, once the later sites have attained the same spiritual status as the former ones, the ordinary pilgrim is admonished to pay respect to the Svayambhūnāth Stūpa and the other places in the Kathmandu Valley, since they are most conducive to spiritual salvation. The section ends thus with the following words:

If one is already liberated from samsāra by just hearing the names of these excellent places, what is there to say about visiting them in person and engaging [there] in meditation and practices like prostrations, offerings and circumambulations? ${ }^{5}$

This section seems to have been added to the register of Nag-dban rdorje at a certain point of time during the circulation of the text, and we only know that it was already part of it when the xylograph was recarved in the $1960 \mathrm{~s}$. As chance would have it, an older version of the work has survived which may contain a clue about the person responsible for bringing about this transformation from register to pilgrimage guidebook. The title of this version differs from the modern edition first in identifying itself as a "concise register" (dkar chag mdor bsdus), a term also used by the author Nag-dban rdo-rje in his short colophon. This older version is also a block print, and contains a printing colophon. Its author is a monk named Blo-bzan Chos-'phel. The printing colophon, introduced by two four-line stanzas, follows immediately after the spiritual exhortation to the pilgrims, and I take Blo-bzan chos'phel to be the one who added this latter to the original register at the time he carved this version. His own words - after a quite elaborate

5 The section called "A Spiritual Exhortation for Pilgrims" is to be found in Wylie, op.cit. (n. 4), p. 47.25-48.9; for the final statement of this section see ibid., p. 48.7-9 (... gnas mchog de rnams kyi mtshan thos pa tsam gyis 'khor ba las grol na I mnion sum du mjal te phyag mchod bskor ba sogs bsgom sgrub la brtson na lta ci smos). The preceeding passage concerning the "prophesied sacred sites" (lun bstan pa' $i$ gnas) for Mi-la-ras-pa and his followers is contained in rJe btsun mi la ras pa'i rnam thar rgyas par phye ba mgur 'bum. Hsining: mTsho-snion mi-rigs dpeskrun khan 1989, p. 122.5-20. It is also quoted in the pilgrimage guidebook to the region of La-phyi gans-ra; see T. Huber, A Guide to the La-phyi Mandala: History, Landscape and Ritual in South-Western Tibet. In: Mandala and Landscape. [Emerging Perceptions in Buddhist Studies 6]. New Delhi: D.K. Printworld 1997, p. 252 . 
description of his birthplace - make it clear that he was especially attracted to the sacred sites of the Kathmandu Valley:

Adjacent of Pulahari in the north, [located] in the middle of a great plain, five and a half miles wide, where saffron grows, and where one can find a cemetery, [a place for] embracing the secret way, [with the name] "Breaking Forth of Great Bliss", and a self-manifested KaṇikaStūpa. The monk Blo-bzan Chos-'phel, who was born in this place, having more and more generated believing faith in these excellent sites [of the Kathmandu Valley], and thinking of the great benefit for himself and others at the time of performing the pilgrimage, printed [this work] in order that the stream of inexhaustible Dharma gifts might increase. [The blocks] remain at the great Stūpa of Bya-run kha-śor. ${ }^{6}$

We do not have any further information concerning Blo-bzan Chos'phel or the date his version of the text was carved on wooden blocks, nor at first sight does the description of his birthplace reveal any geographical details useful for its location. But a still earlier version of Nag-dban் rdo-rje's register which seems to be the original copy has surfaced just recently. It describes not only the stūpa of Svayambhūnāth and other sacred sites in the Kathmandu Valley, but also the reliquary of Ran-rig ras-pa. This monument had been erected in the immediate vicinity of the Bodhnāth Stūpa soon after the death of the 'Brug-pa yogin. It was on the basis of this original that Blo-bzan Chos-'phel had produced his version.

This original edition, again a xylograph, bears the title "Register of [Sacred Sites] like 'All [Kinds of] Trees' in Nepal and the Reliquary of

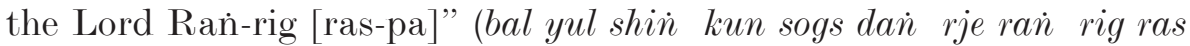
gdun rten gyi dkar chag). ${ }^{7}$ A comparison between the original xylograph

6 See Bal yul mchod rten 'phags pa śin kun dà் de’i gnas gźan rnams kyis (= kyi) dkar chag mdor bsdus (xylograph), NGMPP reel-no. E 816/12, fol. 4b/1-3 (byain phyogs phu la ha ri'i mdun sa / gur gum skye pa'i than chen po dpag tshad phyed dain

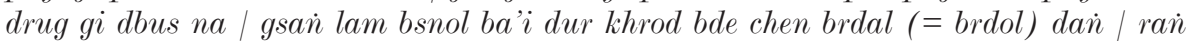
byun mchod rten ka ni ka yod pa / de'i sa char skye pa dge sló blo bzan chos 'phel gyis gnas mchog de rnams la yid ches kyi dad pa ches cher skyes (= bskyes) te / gnas bskor la 'gro skabs rá gźan mań por phan par bsams te / chos sbyin 'dzad med kyi rgyun spel phyir par du bsgrubs te / mchod rten chen po bya run kha śor du bźugs). For the location of the birthplace see n. 12. Compare also G.N. Roerich, The Blue Annals. Delhi: Motilal Banarsidass 1979, p. 400 (“... modern Tibetan pilgrims believe that Pullahari was situated in Kāśmīra in the neighbourhood of Śrīnagar.").

7 This xylograph contains six folios and was made available with the kind help - once more - of Hubert Decleer, Kathmandu. It is the second of a compila- 
and Blo-bzan Chos-'phel's makes it clear that the later version - conceivably produced in the $18^{\text {th }}$ century - while endowing the text with the literary quality of a pilgrimage guidebook, left out a substantial portion of Nag-dban rdo-rje's register (contained between the section on the renovation of Svayambhūnāth Stūpa and the author's colophon). This portion deals with the history of the reliquary of Ran-rig ras-pa and adds a whole new dimension to the text, which up to now has mainly been used for the study of the renovations of Svayambhūnāth Stūpa.

It is interesting to see how Blo-bzan Chos-'phel brought about this transformation from register to pilgrimage guidebook by two changes of the original text: first, by abandoning the portion concerning the reliquary of Ran-rig ras-pa, and, second, by adding the spiritual exhortations to the pilgrims. However, he did spare one part of the deleted passage, namely the quite elaborate description of his birthplace; thus it turns out that he was a monk from Kashmir, and so born in the same region where Ran-rig ras-pa passed away.

In the following I offer a transliterated edition of that part of the original xylograph of Nag-dban rdo-rje which has until now been lost. In the notes to the translation I merely try to pass on some information which may help to place this important work in its historical and cultural context. Under this new perspective, the register describing Svayambhūnāth Stūpa and other sacred sites in the Kathmandu Valley can now be identified as a literary work composed in the year 1686, immediately after the consecration of the reliquary of the Lord Ran-rig ras-pa on the eastern side of Bodhnāth Stūpa.

\section{Translation}

Praise to the Guru!

With devotion I prostrate myself towards the feet of Ran-rig ras-pa, [no one else but]

Padmasambhava, [the teacher who is] the embodiment of the compassion of all the Jinas,

tion of several works, as can be seen from the letter $G a$ on its margin. Like the work of Blo-bzan chos-'phel, it is a large-sized xylograph $(55 \mathrm{x} 9 \mathrm{~cm})$, but its style of printing is different from that of the 'Brug-pa materials of the $17^{\text {th }} / 18^{\text {th }}$ centuries from the Mustang region. As a possible production site of this block print, one could point to such dwelling places of 'Brug-pa yogins as lHa-gdon to the east of the mountain rTsib-ri. 
possessing [the ability of] establishing manifold magical appearances of diligent behaviour,

the protector of gods and men, intimidating the strong and powerful dregs-pa [demons].

Now, if one asks in which way it is taught that this Lord [Ran்-rig raspa] has been prophesied as the heart-incarnation of [the One from] Oḍịāna, [it is said] in the treasure-scriptures of the Vidyādhara Gardban் rdo-rje (1640-1685):

At the border of Mar[-yul] and $\mathrm{Nu}$ in Western Tibet, at a place called "Ran-rig",

a person aware of his own [mind] by himself,

bearing the name "Ran-rig", will appear!

He is the incarnation of my heart:

as spiritual support, he wears the dress of a Cotton-Clad One;

being a yogin, whose diligent behaviour has reached completion, he will bring happiness to India, Tibet [and] Nepal, [these] three!

In particular, he will renovate the [Bya-run] Kha-shor [stūpa], [and] by this [act] foreign armies will be kept back for some years! ${ }^{8}$

And [it is said] in the ninth chapter of the [rDo rje] phag mo gźun drug, [a text] which he had heard from mNa'-bdag Myan-ral bsTan-'dzin chos-dban:

In the Upper Region, there will appear Ran்-rig ras-pa!

He is the incarnation of my heart;

8 There are several texts concerning prophecies in the treasure-cycles of Rig'dzin Gar-dban rdo-rje. See, for example, Lun bstan srid gsum gsal byed, 14 fols., in

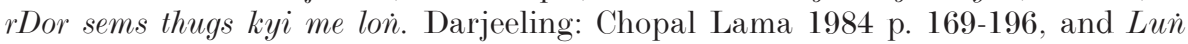
bstan dus gsum kun gsal, 26 fols. \& Lun bstan gsaì ba'i man ñag zab mo, 4 fols., in Thugs rje chen po rtsa gsum sñin thig. Dalhousie: Damchoe Sangpo 1985, p. 259-309 \& 311-318. I was not able to identify any prophecy concerning Rań-rig ras-pa in these texts. For the mention of yul rain rig, located in Spiti, as the place where Ran-rig ras-pa first gave forth spiritual songs, see the collection of his spiritual songs and instructions (as in n. 2), p. $11.2 \mathrm{ff}$. Soon afterwards he visited Jalandhara and other famous Tantric sites in the Western Himalayas; see ibid., p. 19.2ff. 
he will bring happiness to the beings of the six spheres of existence! ${ }^{9}$

In accordance with those scriptures [it is said] on page sixty of the second volume of [the xylograph of] the [auto]biography of the Great All-knowing Powerful Jina, [the Fifth Dalai Bla-ma] Nag-gi dban்phyug Blo-bzań rgya-mtsho (1617-1682):

I met with the one who is known as the Great Siddha Ran-rig from the Upper Region, a person with great experience and understanding of [the doctrines of] the Great Seal and the Great Perfection, [these] two. While [we sat] in a row for tea, a continuing discussion developed [between us]. Some wonder whether he might be the one of whom it is said in the prophecies of mNa'-bdag [Myan-ral Ñi-ma'i 'od-zer]: "From the Upper Region there will appear Ran-rig ras-pa!" In any case, it is obvious that he is a person who has identified [the true nature of] the [outer] appearances and his own mind. ${ }^{10}$

9 A short biographical sketch of the life of Ran-rig ras-pa is to be found in Khetsun Sangpo, Biographical Dictionary of Tibet and Tibetan Buddhism 8. [The bKa'-brgyud-pa Tradition 2]. Dharamsala: Library of Tibetan Works and Archives 1981, p. 413.15-419.14. This sketch is taken from the biography of the 6th 'Brugchen Mi-pham dban-po (1641-1717), who is counted among the students of Rań-rig ras-pa. We find there the episode in which it is narrated that the 'Brug-pa yogin received a prophecy of Vajravarāhī at the time of his pilgrimage to Tsā-ri in southeastern Tibet, and thereupon encountered mNa'-bdag Myan-ral bs'Tan-'dzin chosdban, a descendant of the treasure-discoverer mN்a'-bdag Myan-ral Ñi-ma'i 'od-zer (1124-1196), from whom he received the "teaching cycle of the Black Wrathful One" (khros ma nag mo'i chos skor); see ibid., p. 417.14-19. This happened in the surroundings of sMra-bo $\operatorname{cog}$ in lHo-brag, the family seat of the successors of Myan்-ral Ñi-ma'i 'od-zer. For different ritual texts centering on Vajravarāhī according to this tradition of the rÑin-ma-pa school, see P. Schwieger, Tibetische Handschriften und Blockdrucke. Teil 12. [Verzeichnis der Orientalischen Handschriften in Deutschland 11/12]. Stuttgart: Franz Steiner 1999, p. 3-20.

10 The reference to the block print edition of the autobiography of the Fifth Dalai Bla-ma is correct. See Za hor gyi ban de nag dban blo bzan rgya mtsho' $i$ 'di snan் 'khrul pa'i rol rtsed rtogs brjod kyi tshul du bkod pa du kū la'i gos bzà las glegs bam gñis pa. Gangtok: Sikkim Research Institute of Tibetology 1992, p. 122.3-4 $(=$ fol. $60 \mathrm{~b} / 3-4)$; compare the type set edition, Lhasa: Bod-ljoṅs mi-dmańs dpeskrun khan் 1991, p. 115.13-17. The meeting between Rań-rig ras-pa and Nag-dban Blo-bzan rgya-mtsho took place in the year 1668. It should be noted that the xylograph of this autobiography circulated among 'Brug-pa yogins in the period when the death of the Great Fifth had been concealed by sDe-srid Sańs-rgyas rgya-mtsho (1653-1705). 
This Rań-rig ras-pa, at the time when he was renovating Bya-run khaśor $[s t \bar{u} p a]$, went to the eastern side of [Bya-run] kha-śor [stūpa] and performed [there] just a scattering [of offerings] and then made the prophecy: "In the future, if a reliquary of mine is erected [on this spot], great happiness will arise for beings - and in particular, foreign armies will be kept back - and [thus] joy for Nepal and Tibet!" Then were made ready from [an alloy of] gold and copper the parasol [and] the gañjira top of the great [Bya-run] Kha-śor [stūpa], together with the pillars [holding it] and the supporting pillars. ${ }^{11}$

Again, by way of Western Tibet, after he had spent a winter in Pulahari in the north, [at the time] when he was proceeding to Oḍ̣iyāna in the western direction, he made [another] prophecy: "I myself, a minor meditator, will proceed to O-rgyan glin, [the land of] the beings from Du-va-ri-ka! Then I will make the north of India the place of my death! Erect a relic shrine of mine, at the eastern side of Bya-run kha-śor [stūpa]! In general, [by this act] joy will arise in all [the regions of] Nepal and Tibet, and in particular foreign armies will be kept back for some years!"

Then, although this great Reverend One had reached the completion of the qualities of renouncing and realization without any remainder, in order to produce the seed of the Rūpakāya he abstained from human food. Then, with diligent behaviour, having taken the outer appearence of a yogin - [by smearing] ashes of the dead on his body and so forth - he got with his magic feet to all the sacred sites of Oddiyāna, the island of the Dākin̄is, the land of the Glorious Du-va-ri-ka. And afterwards, in the Mahāvihāra of Nalendra in Kashmir, [located] in the

11 The act of selecting the eastern side of the Bodhnāth Stūpa as the place for the reliquary can be seen as establishing this particular spot as a sacred site. This might have contributed to the situation that the eastern side of Bya-run kha-sor played a role, to some extent, in visions of treasure-discoverers of the r $\tilde{N}$ in-ma-pa school. Remarkable in this respect is the description of the events which brought about the revelation of the Klon chen sñin thig cycle by 'Jigs-med glin-pa (1729/301798) in the year 1757; see J. Gyatso, Apparitions of the Self. The Secret Autobiographies of a Tibetan Visionary. Princeton: Princeton University Press 1998, p. 56-57. 'Jigs-med glin-pa was identified by the dākin̄i on that occasion as the person Sen-ge ras-pa. 
middle of a great plain six and a half miles wide, where saffron grows, adjacent to Pulahari in the north, and where one can find a cemetery, [a place for] embracing the secret way, [with the name] "Breaking Forth of Great Bliss", and a self-manifested Kanika-stūpa, there in the middle of [an area of] 3,700,000 cities, he condensed the visible form of the Rūpakāya into the [sphere of] the Dharmadhātu. ${ }^{12}$

For [the purpose of] a receptacle, in the presence of which the believers are able to collect merit, the tongue, the relics [and] the marvelous residues, which had manifested as godly figures, were taken, according to his prophecy, to the great [Bya-run] kha-śor [stūpa].

A great discussion between the spritual preceptor and the donor [arose] about requesting the king of Kathmandu for the "earth ritual". 'Bramon sgron-pa spoke: "As there are many ministers and great envy [in] this land of Nepal, I will act as a helper for the request in the presence of the king! Tomorrow the king will go to Co-pa in order to meet the deity in the nine-storied [temple]; you and I, [we] two, should thus proceed [there] taking this horse along [with us]! The voice of the ministers should be silenced [by this present] without anyone noticing it!"

In accordance with these words, the host Chos-dban and I, [we] two, brought that good horse along with us and arrived at the nine-storied [temple]. Having offered the horse to the king, who was staying near the god Mahādeva, we then made the [following] request: "Whatever there exists of moulds of bones and relics of the teacher Ran-rig [ras-

12 The residence of the Indian Siddha Nādapāda or Nāropa (956-1040) is known as Pulahari to Tibetan pilgrims, who have paid visits to this site up to the present; for its location in the vicinity of Nālandā in Bihar, see T. Huber, The Guide to India. A Tibetan Account by Amdo Gendun Chöphel. Dharamsala: Library of Tibetan Works and Archives 2000, p. 53. A second Pulahari was located in Kashmir - in the north - and this place served as the starting and returning points for Ranrig ras-pa's journey to Oddiyanna in the final years of his life. It was also near this place that he passed away and that Blo-bzan chos-'phel, the redactor and carver of the register-cum-pilgrimage guidebook, had been born. For one mention of the northern Pulahari in the travelogue of sTag-tshan ras-pa (1574-1651), another 'Brug-pa yogin, who reached Kashmir and its sacred sites in the period between the years 1613 and 1616, see G. Tucci, Travels of Tibetan Pilgrims in the Swat Valley. Calcutta: The Greater India Society 1940, p. 69. The relocation of Pulahari to the north was accompanied by a similar relocation to Kashmir of the prestigious Buddhist monastery of Nālandā (= Nalendra). 
pa], who has passed away [recently], we plan to erect [for them] a reliquary at [Bya-run] kha-śor [stūpa], and therefore it is necessary that you grant your favour for the "earth ritual"! We having extensively offered this request [to him], the king replied: "As the teacher [Ran-rig ras-pa] showed great benevolence to me, perform whatever 'earth ritual' is necessary!" Not long after his reply, there were inserted four turquoise ornaments under his feet, [which is a sign of] a great oath according to Nepalese customs. ${ }^{13}$

Afterwards, when King Pārthivendra Malla had returned to his palace, the ministers and great elders came together and spread malicious rumours to the king [with the words]: "There is no historical record that Tibetan stūpas have been erected in Nepal before. As Tibet is great in agitating means, [there is] every reason not to be happy with permission for the construction of the stuppa." The king replied: "In general, the teacher [Rań-rig ras-pa] has been greatly benevolent to me, and the object to which his heart is directed is [Bya-run] kha-śor [stūpa]. Moreover, turquoise ornaments having been inserted under my feet in the presence of Mahādeva, it was said [already] that they can perform whatever "earth ritual" is necessary. As therefore [permission] has already been given, [the matter] is settled." Although the ministers entertained greed, they found no opportunity [to satisfy it] and were freed from their malicious rumours [by this]. ${ }^{14}$

13 The toponym Co-pa stands for Chobar or Chobāra, a hill to the south-west of the Kathmandu Valley. On the top of this hill is a temple housing a statue of Padmapanni Lokeśvara, which goes also by the name Ādinātha. The Sixth Źvadmar-pa Chos-kyi dbań-phyug (1584-1630) saw this statue during his visit to the Valley and identified it as one of the famous self-arisen effigies of the "Brothers Ārya [Avalokiteśvara]" ('phags pa sku mched). See Bal yul du bgrod pa'i lam yig nor bu spel ma'i 'phren ba, NGMPP reel-no. L 387/3, fol. 24a/2-3; for a description of this interesting travelogue compare: F.-K. Ehrhard, "The Lands are like a Wiped Golden Basin". The Sixth Źva-dmar-pa's Journey to Nepal and his Travelogue (1629/30). In: Les habitants du toit du monde. Études recueillies en homage à Alexander W. Macdonald. [Recherches sur la Haute Asie 12]. Nanterre: Société d'ethnologie 1997, p. 126-128. The fact that during the rulership of King Pārthivendra Malla - one of the sons of Pratāpa Malla (regnal years 1641-1674) - the statue was regarded as Mahādeva, i.e. Siva, points to the change in the political and religious climate in Nepal caused by the Shah dynasty. The year 1685 actually marks the embarkation of the Gorkhalis on the long course dedicated to winning the Malla realms; see M.S. Slusser, Nepal Mandala. A Cultural Study of the Kathmandu Valley. Princeton: Princeton University Press 1982, vol. 1, p. 65.

14 This episode of the king's consent to the construction of the reliquary, its being questioned by his advisers and ministers, and the final reconfirmation, calls 
Then, on the seventeenth day of the eleventh Hor month of the woodox [year] [=1685], when the propitious constellation for the construction [in general] and for [the manufacturing of] the bricks was performed, there was a surprise, for there were brick marks and human footprints clearly visible on each of the bricks. Although rain falls in Nepal without [a distinction between] summer and winter, in this year it was falling everywhere else in Nepal, but it did not rain at [Bya-run] kha-śor [stūpa]: thus [the manufacturing of] the bricks could be completed without any disturbance.

Afterwards, when the earth had been dug out at the eastern side of [Bya-run] kha-sor [stūpa], at the time of laying the foundation, Padma rdo-rje, the "lord of the site", the master [and] his disciples, uttered manifold harmful words, such as: "I am the 'lord of the site"! [Just] having asked the king [for permission] is not sufficient!" On top of that, even the people from my own quarters showed unsuitable behaviour, and after a Nepalese had carried away what was in the way of tools, they [too] escaped by running away.

When I was sitting the whole night [outside] in the field, thinking: "Someone without water here in Nepal, it seems, has to buy it! Now it is [definitely] decided that the reliquary [of Ran-rig ras-pa] cannot be completed. The teacher, the personal deity and the $d \bar{a} k i n \bar{\imath}$ will have to give their blessings that the aim of my thoughts can be accomplished! Lacking that, I would rejoice even in dying!"

In a dream at the break of the day, having arrived at the top of a round-shaped mountain to the west of the lake Manosarowar, I saw in the space in front [of that site,] inside a house [which was] a tent of

to mind the myth of the construction of the Bodhnāth Stūpa and the etymology of its alternative name "Permission To Do What Is Proper" (bya run kha śor). Concerning the literary sources of these events, see F.-K. Ehrhard, The Stūpa of Bodhnāth: A Preliminary Analysis of the Written Sources. Ancient Nepal: Journal of the Department of Archaeology 120 (October-November 1990) 2, n. 2, and A.M. Blondeau, Bya-run kha-shor, légende fondatrice du bouddhisme tibétain. In: Tibetan Studies 1. [The Institute for Comparative Research in Human Culture, Occasional Papers 1,1]. Oslo: Institute for Comparative Research in Human Culture 1994, p. $31-48$. 
rainbows, the great Reverend One Rań-rig ras-pa himself: his body of greater majesty than even before, having the external appearance of a Heruka, emitting light and being of great dignity. Thinking: "It seems that my teacher has not died [yet]!", in a state of both joy and sorrow, [these] two, [I felt] tears coming forth in great number and was not able to address him from my side. [Thus] the Lord [Rań-rig ras-pa] spoke:

You, showing pride, by saying "I have done [so much already]" abandon your thoughts completely and listen in a clear way: the soil of the self-arisen Ālaya[vijñāna] I have identified with a benevolence which is incomparable;

the full-grown sprout of spiritual experience has developed, [and] the fruit has ripened [now] - the three Kāyas, [nothing else but] one's own mind!

I, the yogin without fixed abode, who has abandoned ordinary deeds

to accomplish the benefit of beings in an impartial way:

although [I] have shown the vanishing of the body [constituted by] causes, outside,

the self-arisen awareness, inside, exists as something unchangeable; don't you act in a timid fashion -

let your mind be at ease [in the state of] Reality-as-it-is!

You, [who are] someone saying "I", if you are able to listen [to me]: don't strive for [the world of] conditioned factors worry about the mind which is unconditioned!

Thinking: "What is changing has no truth!", dismiss the ordinary deeds of this life

[and] rely on remote mountain hermitages in an unattached way!

Keep up the original [mind of] recollection [and] knowing as a spiritual practice!

If you have severed the doubts arising from grasping [mind and object] as two,

why should you not be victorious over the demon of obstacles?

At the very moment this was said I awoke from sleep and the night had departed. Although I set it down immediately in writing, some words I obviously forgot - a dream it is indeed something distorted! 
Then, after the mind of Padma rdo-rje, the "lord of the site", had also been freed [from doubts], in accordance with the shape of [Bya-run] kha-śor $[s t \bar{u} p a]$, there was constructed underground the "mountain", the ten virtues [platform], the stairs [and] the "lion throne" up to the first level. When that was reached, [the stüpa] was built above the ground: in the four directions of the central part [of the edifice] were statues manufactured from black stone, [one] of Śākyamuni [Buddha] and three of [Padmasambhava as] Dharmakāya, Saṃbhogakāya and Nirmāṇakāya [i.e. Amitābha, Avalokiteśvara and Padmasambhava], [and] a circle of Yakșa [deities] in relief from [an alloy of] gold and copper. Above that was the treasury of the central part [of the stūpa], nineteen cubits [high], equivalent to the size of the central beam (yasti) [made of] sal wood; from its base up to its summit [were] containers of dhāraṇis with all the proper signs.

In the interior of the bulging [body] of the central part [of the stuppa] was a chamber made from copper for the heart, tongue [and] eyes, [all] three, of the Lord [Ran-rig ras-pa]. [Further] contained [in the interior] was a cup full of relics, 5,300 tsha[-tsha images] from his [fragmented] bones, countless kinds of blessed sacred objects, including fifteen statues and thain[-kas], the main ones being statues and thain[-kas] of the five classes of [the deity] Khros[-ma] nag[-mo], which were resistent to fire.

[The stüpa] was [then] completed in brick, without [any difference between] inside and outside. As for the size, [it was] twenty cubits in each of the [four] directions; from the base to the top [it was] thirty-one cubits [high]. The umbrella [and] the gañjira, together with the top fastened to it, were manufactured from [an alloy of] gold and copper.

In accordance with the prophecy of the teacher [Ran-rig ras-pa] the shape resembled [Bya-run] kha-śor [stūpa] in the same way as a son bears [a resemblance to] his mother. On the thirteenth day of the fourth Hor month of the fire-tiger [year] [=1686], an assemblage of a crowd of 6,700 persons from Nepal, Tibet and the gorges, and seventy male and female practitioners - headed by Padma rdo-rje, the upādhyāya for the consecration [ceremony], and by Chos-grags rgya-mtsho - arranged for a feast in a proper way; and there was a scattering of flowers 
accompanied by wondrous signs. The consecration [ceremony] was performed one more time by Zil-gnon dBań-rgyal rdo-rje (1647-1716), the holder of the family-lineage of lHa-lun dPal-gyi rdo-rje. ${ }^{15}$

$[9]$

In such a way, after body, speech and mind of myself and others have been purified and cleaned in the presence of this receptacle, together with the multitude of impurities and sins of the two kinds of obscurations - assembled from beginningless lives up to the present by countless beings, who by [the acts of] seeing and listening have established a connection with material things - may the two kinds of accumulations be completed; and having [finally] reached in this life the state of a Buddha, by benefiting others without [treating them as] particular objects, may the benefit of the teachings and of the beings, [which is] similar to the sky [in its extent], be accomplished without any effort!

\section{EDITION}

Bal yul shin kun sogs dan் rje rań rig gdun rten gyi dkar chag fols. $4 \mathrm{a} / 3-6 \mathrm{a} / 4$

namo guru /

rgyal kun thugs rje'i spyi gzugs padma 'byun / brtul źugs rdzu 'phrul sna tshogs bkod pa can / mthu stobs dregs pa zil gnon lha mi'i mgon / rań rig ras pa'i źabs la gus pas 'dud/

15 Up to now I have no further information on the persons of Padma rdo-rje and Chos-grags rgya-mtsho. For biographical data concerning Zil-gnon dBanrgyal rdo-rje - who had received this name from the Fifth Dalai Bla-ma Nag-dban Blo-bzan் rgya-mtsho - see F.-K. Ehrhard, A Forgotten Incarnation Lineage: The Yol-mo-ba sPrul-skus (16 $6^{\text {th }}$ to $18^{\text {th }}$ centuries). In: The Pandita And The Siddha. Tibetan Studies in Honour of E. Gene Smith. Boston: Wisdom Publications (forthcoming). The father of Zil-gnon dBan-rgyal rdo-rje, a disciple of the Third Yol-mo-ba sPrul-sku bsTan-'dzin nor-bu, was regarded as an incarnation of lHa-lun dPal-gyi rdo-rje; this incarnation status led family members to appropriate the name. This family acted as caretakers of the Bodhnāth Stūpa, and it is recorded that Zil-gnon dBań-rgyal rdo-rje carried out renovation work at Bya-run kha-śor in the years $1706 / 1707$. 
de yan் rje de ñid ni o rgyan thugs kyi sprul par lun bstan pa yin te / ji ltar bstan ce na / rig ${ }^{16}$ 'dzin gar dbań rdo rje'i gter lun las /

mn்' ris mar nu'i so mtshams su :

yul ni rań rig ces bya ru :

skyes bu ran gis rań rig pa'i :

ran் rig ces bya'i miń can 'byun :

de ñid na ñid thugs sprul ste :

rten ni ras pa'i cha byad can :

brtul źugs mthar phyin rnal 'byor pa :

rgya bod bal gsum bde la 'god :

lhag par kha shor ñams gsos byed :

des ni mtha' dmag lo 'ga'17 bzlog:

ces dan்/

mn்a' bdag ñan் ral bstan 'dzin chos dban் nas gsan pa'i phag mo gźun drug le’u dgu pa las /

stod kyi phyogs su ran் rig ras pa 'byun :

de ni kho bo'i thugs kyi sprul pa'o :

des ni 'gro drug sems can bde la 'god:

ces pa'i lun dan் mthun par rgyal dban் thams cad mkhyen gzigs chen po ṅag gi dbań phyug blo bzan் rgya mtsho'i rnam par thar pa kha pa'i grańs yig drug cu par/

la stod phyogs nas ran rig grub chen du grags pa phyag rdzogs gñis ka la ñams rtogs che ba źig 'oṅs par dań phrad de / ja gral la 'phros glen்s man் du byun் / la las mn்a' bdag gi lun bstan du / stod kyi phyogs nas ran் rig ras pa 'byun : źes pa de yin nam zer / gan் ltar [4b] snań sems ran் ṅo 'phrod pa źig tu mn்on /

$[2]$

źes gsuṅ pa’i rje ran் rig rig ras pa de ñid kyis bya run kha śor gyi ñams gsos mdzad dus / kha śor śar 'dabs su phebs nas 'thor tsam źig mdzad nas ma 'oṅs pa ṅa'i gdun rten źig bźen்s na sems can la bde rgya che dan் lhag par mtha' dmag bzlog pa dan் / bal bod la bde skyid 'byuń źes lun bstan / de nas kha śor chen po’i gdugs gandzira tog dan் / ka ba ka

16 rigs.

17 bga'. 
sten dan் bcas pa gser zan்s las grub pa mdzad / slar mn்' ris brgyud nas byan் pu la ha rir dgun thog geig bźugs nas nub phyogs o rgyan la phebs dus / ṅa sgom chun du va ri ka pa / 'gro ba o rgyan glin் du 'gro / śi sa rgya gar byan் du byed / bya run kha śor śar 'dabs su / mi kho bo’i gdun rten de ru bźen்s / spyir bal bod kun la bde skyid 'byun / sgos mtha' dmag lo 'ga' bzlog par 'gyur / ces lun bstan /

de nas rje btsun chen po de ñid spańs rtogs kyi yon tan ma lus pa mthar son kyan் / gzugs sku'i sa bon bskrun phyir mi zas rnams span்s / sku la thal chen sogs dzo ki'i chas bzun / brtul bźugs kyi spyod pas o rgyan mkha' 'gro glin dpal du va ri ka'i yul gnas thams cad rdzu 'phrul źabs kyis brtol ${ }^{18}$ nas slar byań phyogs ${ }^{19}$ phu la ha ri'i mdun sa / gur gum skye pa'i than் chen po dpag tshad phyed dan் drug gi dbus na / gsań lam bsnol ba'i dur khrod bde chen brdol ${ }^{20}$ dan் / ran் byun mchod rten ka ṇi ka yod pa / gron் khyer 'bum phrag so bdun yod pa'i dbus su / kașmi na lendra'i gtsug lag khan chen por gzugs sku'i bkod pa chos dbyin்s su bsdus śin / dad ldan bsod nams bsog rten du ljags rin bsrel ${ }^{21}$ / no mtshar sku tshigs lha skur byon pa rnams lun bstan bźin kha śor chen po’i drun du spyan drańs te /

yam bu rgyal po la sa dpyad źu ba'i mchod yon bka' bgros che / 'bra mon sgroń pa na re / bal yul 'di blon po mań źiń phrag dog che bas / rgyal por nass źu rogs bya'o // sañ ñin rgyal po co par dgu thog tu lha mjal du phebs 'on bas / khyed ran் gñis rta 'di khrid las śog / blon po rnams kyi ma tshor bar ṅag chod pa bya'o // zer ba bźin rań gnas po chos dban் gñis kyis ${ }^{22}$ rta bzan் po de khrid dgu thog tu phyin pas / rgyal [5a] po lha ma hā de va'i drun na bźugs pa la rta phul nas źus pa / bla ma rań rig źin la phebs pa’i gdun் rus spar gań yod pa / kha śor du gdun rten bźen் rtsis lags pas sa dpyad bka' drin skyon dgos tshul ${ }^{23} \mathrm{~g}^{2} \mathrm{i}^{24}$

\footnotetext{
18 btol.

19 phyags.

20 brdal.

21 srel.

22 kyi.

23 chul.

24 gya.
} 
źu ba rgyas par phul bas / rgyal po na re / bla ma khon̉ ṅed la bka' drin che bas sa dpyad gan du dgos kyan gyis ${ }^{25}$ śig gsuns byun bas / gsuns ma thag źabs 'og tu pra men bźi bcug pa bal lugs kyi mna' chen po yin / de nas rgyal po pa ti phhendra ma la pho brań du byon pa la / blon po dań rgan chen rnams 'dus nas rgyal por / bal yul du snar nas bod kyi mchod rten bźeńs pa'i lo rgyus med / bod g.yo thabs che bas mchod rten bźen du bcug pa mi dga' ba’i rgyu mtshan gyi phra ma źus tshe / rgyal po'i źal nas / spyir bla ma koń naa ran la bka' 'drin che ba dan் / thugs kyi gtad sa kha śor yin / lhag par ma hā de va'i drun du / rkan 'og tu pra men bcug ste ${ }^{26}$ sa dpyad gań dgos gyis śig ces sbyin tshar bas kha bsdus gsuns / blon po rnams za 'dod byed run / glags ma rñed cin phra ma las grol/

$[5]$

de nas śin glan hor zla bcu gcig pa'i tshes bcu bdun gyi ñin / bzo rigs dan் / rtsa phag gi skar 'dzin byas pas / rdza phag re re la phag rjes mi'i rkań rjes cam lam mer bsal bas ṅo mtshar bar byun / bal yul du dbyar dgun med par char 'bab kyan் / de'i lo la bal yul gźan du babs kyan் / kha śor du ma babs pas rdza phag gi mgo thon /

de nas kha śor śar 'dabs su sa brus nas rmań gtin tshe / gnas bdag dpon slob padma rdo rjes / gnas bdag ned yin / rgyal po la źus pas go mi chod sogs bka' skyon sna tshogs gnan ba'i stens su / rañ phyogs rnams kyis kyan் mi 'tshams pa'i spyod 'gros dan் / chas yod pa rnams bal po źig gis $^{27}$ khyer nas bros la śor / bal yul 'dir chu min pa ño dgos 'dug / da ni gdun rten mi 'grub thag chod / bla ma yi dam mkha' 'gros bdag gi bsam don 'grub par ${ }^{28}$ byin gyis rlobs śig / de min śi ba ran dga' sñam mtshan gan du źin sdad pa las / tho ran்s ${ }^{29} \mathrm{rmi}$ lam du / ma pham yin zer ba'i mtsho źig gi nub ri ldum po źig gi rtser sleb pa'i mdun gyi mkhar 'ja' 'od kyi gur khyim gyi nan் na / rje btsun chen po rań rig ras pa de yid sñar ba kyan் sku [5b] gzi byin che ba he ru ka'i cha byad 'od zer 'phro źin zil che ba źig mthon bas / ṅa'i bla ma ma grońs pa 'dug sñam dga'

\footnotetext{
25 gyas.

26 sta.

27 gi.

28 'grab par.

29 tho ran
} 
ba dan் skyo ba gñis ka’i ṅań nas mchi ma man் du śor źin் phar źu ma nus / rje’i źal nas /

khyod ṅa byas zer ba'i khon yus can /

sems lhug par źog la lhan ner ñon /

ned kun gźi rań byuñ ${ }^{30}$ gi źin் sa la /

bka' drin mñam med kyis ${ }^{31}$ ran் ṅo sprad/

ñams myon tshad ldan gyi ${ }^{32}$ myu gu rgyas /

ran் sems sku gsum gyi 'bras bu smin /

'gro don phyogs med du 'grub pa yi /

bya btan் ṅes med kyi rnal 'byor ṅa/

phyi rgyu lus kyi rnam 'gyur bstan mod kyan் /

nan் ran் byun gi rig pa 'pho 'gyur med/

mi khyod ran் blo ${ }^{33}$ chun ma byed par /

blo sems chos ñid du bde bar gyis /

mi ṅa zer khyod rań ñan srid na/

'dus byas gñer srid'34 ma byed par/

byar med kyi sems la ña ra gyis /

rnam 'gyur la ṅes pa mi 'dug go /

bsam bźin du tshe 'di'i bya ba thon /

nes med kyi ri khrod dben pa brten ${ }^{35} /$

ñams ${ }^{36}$ len du dran śes rnal ma skyon்s /

gñis 'dzin gyi the tshoms rbad chod na /

bar chad kyi bdud las cis mi rgyal /

ces gsuńs pa'i mod la gñid sad pas nam lańs 'dug / de ma thag yi ger bkod kyan் tshig 'ga' brjed 'dug / rmi lam 'khrul pa yin mod /

de $^{37}$ nas gnas bdag gi dgoṅs pa yan் grol nas / kha śor gi bzo dbyibs ji lta ba bźin / sa 'dzin dge beu ba dan them skas sen் khri ban் rim ${ }^{38}$ dan் po ${ }^{39}$

\footnotetext{
30 byan்.

31 kyi.

32 gya.

33 bla.

34 srad.

35 brtan.

36 ñam.

37 da.

38 bam ram.

39 dań pa.
} 
man chad sa 'og tu mtshon par byas / de phyin sa steñs su brtsigs pa / bum pa'i phyogs bźir sākya thub pa dan / chos loṅs sprul gsum gyi sku rdo nag las grub pa / gnod sbyin 'khor lo gser zańs 'bur dod / de sten bum gter spos dkar śin gi srog śin cha tshad dan mtshuñs pa khru ${ }^{40}$ bcu dgu / źabs mthil nas dbu'i gtsug tor gyi bar gzuṅs bźugs mtshan ñid kun ldan / bum ldir nan du rje'i ${ }^{41}$ thugs ljags spyan gsum bźugs khan $\mathrm{zi}^{42}$ khyim las grub pa / rin srel tiń gan / gdun tsha lńa ston் gsum brgya / khros nag sde lna'i sku than me thub mas gtsos pa'i sku than bco lña sogs byin rlabs rten gyi rigs dpag tu med pa ${ }^{43}$ bźugs / phyi nań med pa rdza phag la grub pa / rgyar phyogs re la khru ñi śu / rtsa rtse’i bar la khru sum cu so geig / gdugs gañdzira ${ }^{44}$ 'phren tog dan bcas pa gser zańs pa bsgrubs /

[8]

bla ma'i lun bstan bźin ${ }^{45}$ bzo dbyibs [6a] kha śor ji lta ba ma gan du bu blañs pa lta bu / me stag hor zla bźi pa'i tshes bcu gsum kyi ñin rab tu gnas pa'i mkhan po padma rdo rje / chos grags rgya mtshos gtsos / sgrub pa pho mo beu phrag bdun dan / bal bod ron் gsum gyi khrom drug ston bdun brgya tshogs / dga' ston legs par bśams śin / ṅo mtshar ltas dan் bcas te me tog 'thor / slar yan் lha lun dpal gyi rdo rje'i gdun srol 'dzin pa zil gnon dban rgyal rdo rjes rab tu gnas par mdzad /

de ltar rten ${ }^{46}$ 'di ñid la bdag gźan lus nag yid gsum dan / zań zin gi 'brel thogs mthon thos kyi 'gro ba ma lus pa'i tshe thog ma med nas da bar du bsags pa'i sdig sgrib gñis ${ }^{47}$ ltun dri ma’i tshogs kun byań źin dag nas / tshogs gñis rdzogs te sańs rgyas kyi go 'phan tshe 'di ñid la thob nas / dmigs pa med pa'i gźan don gyis bstan pa dan sems can gyi don nam mkha' dan் mñam par 'bad med du 'grub par gyur cig gu /

\footnotetext{
40 'khru.

41 rjes.

42 gzi.

43 mad pa.

44 gañdzara.

45 bźan.

46 rtan.

47 ก̃as.
} 
Note on the illustration on p. 146:

The book An Account of the Kingdom of Nepal and of the Territories Annexed to this Dominion by the House of Gorkha by Francis Hamilton (Edinburgh: A. Constable, 1819) contained two copperplate engravings taken from drawings by Charles Crawford. One showed the Bodhnāth Stūpa together with the reliquary of Ran-rig ras-pa: it is the first Western representation of Tibetan monuments in the Kathmandu Valley. Crawford, who later became head of the Cartographic Survey of India, also left several manuscript maps of the Valley and of the route from India to Nepal. For the remarkable precision and aesthetic quality of these maps, see L. Boulnois, Bibliographie du Nepal. Vol. 3 (Sciences Naturelles), Tome 1 (Cartes du Nepal dans les bibliothèques de Paris et de Londres). Paris: Éditions du Centre national de la recherche scientifique 1973, p. 31. Compare also J. Keay, The Great Arc. The Dramatic Tale of How India Was Mapped and Everest Was Named. London: Harper Collins 2000, p. 35-38, for Crawford's attempts to measure the Himalayas.

The illustration has been reproduced from a copy preserved at the Austrian National Library, Vienna. 
